\title{
Public Notary Services In Malaysia
}

\begin{abstract}
Thaufiq Deen ${ }^{1}$; O. Argo Victoria²; Sumain ${ }^{3}$
Abstract. Starting January 5, 2015 the Embassy in Kuala Lumpur requires appointments for all notarial services. Please bring your appointment confirmation sheet and arrive at the embassy 10 minutes before the appointment time ${ }^{4}$. It can provide most of the same notarial services that a public notary is authorized by law to perform within the United States. Services are similary available as in U.S. and to foreign nationals with documents intended for use within the U.S. By following to the ACS Unit when requesting notary services: The documents to be notarized, including attachments, if any. The passport and one other photo identification. Witnesses, if required. (Consular staff are not alloitd to serve as witnesses.) $\$ 50.00$ or the equivalent in Malaysian ringgit for each seal. Notary fees can be paid in cash or by credit card.

Keywords: Notary, Management, Malaysia.
\end{abstract}

\section{Introduction}

A notary public (or notary or public notary) of the common lawis a public officer constituted by law to serve the public in non-contentious matters usually concerned with estates, deeds, powers-of-attorney, and foreign and international business. A notary's main functions are to administer oaths and affirmations, take affidavits and statutory declarations, witnessand authenticate the execution of certain classes of documents, take acknowledgments of deeds and other conveyances, protest notes and bills of exchange, provide notice of foreign drafts, prepare marine or ship's protests in cases of damage, provide exemplifications and notarial copies, and perform certain other official acts depending on the jurisdiction. Any such act is known as a notarization. The term notary public only refers to common-law notaries and should not be confused with civil-law notaries ${ }^{5}$.

All blank spaces (other than signatures) must be adequately filled in before the document can be notarized. It has blank affidavit and acknowledgement forms available for the use, but cannot provide any advice on wording any document or completing any forms. Be advised that it cannot certify any civil documents (e.g., birth, marriage and death certificates) or any documents issued by government authorities in Malaysia or the U.S. (e.g., drivers licenses) except through authentication, which is a complicated and time-consuming process. It also cannot certify any educational documents, e.g., diplomas and transcripts ${ }^{6}$.

Notaries are appointed by a government authority, such as a court or lieutenant governor, or by a regulating body often known as a society or faculty of notaries public.

\footnotetext{
${ }^{1}$ Student of IRKHS International Islamic University Malaysia, Email: thaufiq.deen@iium.my

${ }^{2}$ International Islamic University Malaysia Reseacher, Email: argovictoriaupin@gmail.com

${ }^{3}$ Faculty of Law Unissula Semarang email: main.smicecomm@gmail.com

4 https://evisaforms.state.gov/acs/default.asp?postcode=KLL\&appcode $=1$, Accessed on $15^{\text {th }}$ February 2019

5 Hai, Jeong Chun; Nawi, Nor Fadzlina (2007). Principles of public administration: an introduction. Shah Alam, Selangor: Karisma Publications.

${ }^{6}$ Chooi, Clara. "Putrajaya Reports Increase in Non-Bumiputeras in Civil Service". The Malaysian Insider, p. 45
} 
For lawyer notaries, an appointment may be for life, while lay notaries are usually commissioned for a briefer term, with the possibility of renewal.

In most common law countries, appointments and their number for a given notarial district are highly regulated. However, since the majority of American notaries are lay persons who provide officially required services, commission numbers are not regulated, which is part of the reason why there are far more notaries in the United States than in other countries (4.5 million vs. approx. 740 in England and Wales and approx. 1,250 in Australia and New Zealand). Furthermore, all U.S. and some Canadian notarial functions are applied to domestic affairs and documents, where fully systematized attestations of signatures and acknowledgment of deeds are a universal requirement for document authentication. By contrast, outside North American common law jurisdictions, notarial practice is restricted to international legal matters or where a foreign jurisdiction is involved, and almost all notaries are also qualified lawyers ${ }^{7}$.

For the purposes of authentication, most countries require commercial or personal documents which originate from or are signed in another country to be notarized before they can be used or officially recorded or before they can have any legal effect. To these documents a notary affixes a notarial certificate which attests to the execution of the document, usually by the person who appears before the notary, known as an appearer or constituent (U.S.). In places where lawyer notaries are the norm, a notary may also draft legal instruments known as notarial acts or deedswhich have probative value and executory force, as they do in civil law jurisdictions. Originals or secondary originals are then filed and stored in the notary's archives, or protocol.

\section{Discussion}

\subsection{Basic Notary Law in Malaysia}

If the people should require Public notary services for any of the matters listed below please feel free to call up for an appointment:

\subsubsection{Scope of Public notary's Role extracted from Act 115 on Public notary Act 1959 Section 4 on Privileges of Public notary:}

4. (1) Every public notary shall have and may exercise within his place of practice all the poitrs and functions which are ordinarily exercised by public notary in England: Provided that, except for the purposes of and to the extent necessary to give effect to subsection (2), such poitrs shall not include poitr to administer any oath or affirmation in connection with any affidavit or statutory declaration which is executed for the purpose of being used in any court or place within Malaysia, or to take or attest any such affidavit or statutory declaration.

4. (2) Without prejudice to the generality of the poitrs and functions conferred by subsection (1), a public notary may: (a) administer any oath or affirmation in connection with any affidavit or statutory declaration which is executed:

- for the purpose of confirming or proving the due execution of any document;

- by any master or member of the crew of any vessel in respect of any matter concerning that vessel; or note on the poitrs and functions ordinarily exercised by

\footnotetext{
${ }^{7}$ Chooi, Clara. "Putrajaya Reports Increase in Non-Bumiputeras in Civil Service". The Malaysian Insider, p. 45
} 
public notary in England is to be found at page 1119 of Vol. 23 of the $3^{\text {rd }}$ Edition of Halsbury's Statutes of England ${ }^{8}$.

- for the purpose of being used in any court or place outside Malaysia, and may take or attest any such affidavit or statutory declaration; and

- have and exercise such other poitrs and functions as may be prescribed.

Public notary's Role in Authenticating Poitr of Attorney extracted from Act 424 Poitrs of Attorney Act 1949, Section 3 on Authentication of Poitrs of Attorney:

3. (1) No instrument purporting to create a poitr of attorney executed after the commencement of this Act shall have any validity to create such poitr within Peninsular Malaysia unless.

- if executed within Peninsular Malaysia, the instrument is executed before, and is authenticated in the appropriate form set out in the First Schedule hereto by: (i) a Magistrate; (ii) a Justice of the Peace; All references to "Itst Malaysia" shall be construed as reference to "Peninsular Malaysia") (iii) a Land Administrator; (iv) a Public notary; (v) a Commissioner for Oaths; (vi) an advocate and solicitor; or (vii) an officer, acting in the course of his employment, of a company carrying on the business of banking in Peninsular Malaysia and incorporated by or under any written law in force in Peninsular Malaysia; or

- if executed outside Peninsular Malaysia, the execution of such instrument is authenticated, in such form as may be accepted by the Registrar, by:- (i) a Public notary; (ii) a Commissioner for Oaths; (iii) any Judge; (iv) a Magistrate; (v) a British Consul or Vice-Consul; (vi) a representative of Her Britanic Majesty; (vii) on and after Merdeka Day, any Consular Officer of Malaysia; (viii) in the case of an instrument executed in the Kingdom of Saudi Arabia, the Malaysian Pilgrimage Commissioner; or (ix) in the case of an instrument executed in the Republic of Singapore' an advocate and solicitor of the Supreme Court of the Republic; or an officer, acting in the course of his employment, of a company carrying on the business of banking in the Republic and incorporated by or under any written law of the Republic.

3. (2) Notwithstanding anything to the contrary contained in any written law in force at the commencement of this Act, an instrument purporting to create a poitr of attorney duly executed and authenticated in accordance with this section shall be deemed to be properly and validly executed and attested for all or any of the purposes for which a poitr of attorney may be used under any such written law ${ }^{9}$.

Role of Commissioner For Oath and Public notary in respect Statutory Declaration (Extract from Act 13- Statutory Declaration Act 1960) Section 2:

2. It shall be lawful for any Sessions Court Judge, Magistrate, or Commissioner for Oaths or, subject to section 4 of the Public notary Act 1959 [Act 115], any public notary appointed under the Public notary Act 1959, to take and receive the declaration of any person voluntarily making the same in Malay or English in the form in the Schedule ${ }^{10}$.

\subsubsection{A brief List of Public notary services pursuant to the Public notary Act 1959:}

8 http://exfacie.com/?q=notaries halsburys laws of england 1st edition, Accessed on $15^{\text {th }}$ February 2019

${ }^{9}$ http://www.agc.gov.my/Akta/Vol.\%209/Act\%20424.pdf, Accessed on 15 $15^{\text {th }}$ February 2019

${ }^{10}$ www.agc.gov.my/Akta/Vol.\%201/Act\%2013.pdf, Accessed on 15 th February 2019 
- witnessing/ attesting any official documents intended for overseas use;

- the administration of oaths intended for overseas use;

- affirmations of affidavits and statutory declarations intended for overseas use:

- in respect of any courts matters;

- for proving due execution of any document;

- for matters pertaining to a sea vessel.

1. This Act may be cited as the Notaries Public Act 1959.

2. In this Act, unless the context otherwise requires "Bar Council" means the central council of the Malaysian Bar established under section 47 of the Legal Profession Act 1976 [Act 166]; "notary public" means a person who has been appointed as a notary public under section 3 but does not include any person whose appointment has been revoked under section 5; "place of practice" means the territory or part thereof within which a person is appointed to practise as a notary public under section 3; "prescribed" means prescribed by or under this Act; "State Attorney General" means the State Attorney General, Sabah, or the State Attorney General, Sarawak, as the case may require.

In its application to Sabah and Sarawak-see L.N. 98/1965. 6 Laws of Malaysia ACT 115 Appointment of notaries public

3. (1) Subject to subsection, the Attorney General may, from time to time, appoint fit and proper persons to be notaries public to practise within Peninsular Malaysia or Sabah or Sarawak or such part of those territories for such period as may be specified in the appointment.

(1A) Notwithstanding any other law to the contrary, where any person has been appointed to be a notary public before the coming into force of this subsection and no period is specified in that appointment, the appointment shall cease to have effect upon the expiry of the period of two years from the date of coming into force of this subsection.

(1B) Nothing in subsection (1A) shall be construed as preventing the reappointment under subsection (1) of any person whose appointment has ceased to have effect by virtue of subsection (1A), and every such reappointment shall be deemed to be a new appointment.

(2) No person shall be appointed to be a notary public unless he is a practising advocate or a pleader licensed under the Pleaders and Petition Writers Enactment of the State of Terengganu [Tr. 59 of 1356] and who was so licensed before 1 January 1956: Provided that in any place in which a suitable advocate is not available for appointment, the Attorney General may, in his discretion, appoint a public officer to be a notary public, and any fees received by a public officer so appointed in respect of his functions as a notary public shall be paid into the Consolidated Fund. (3) The Attorney General shall not make any appointment under this section without consulting the Bar Council or, in relation to Sabah or Sarawak, without consulting the State Attorney General. (4) In making any appointment under this section the Attorney General shall have regard to the number of notaries public already practising in the place where the applicant proposes to practise and to the convenience of the inhabitants of such place, but, subject as aforesaid, the Attorney General shall have absolute discretion in making or refusing to make any such appointment and there shall be no appeal from his decision.

(5) If it shall appear to the Attorney General or, where the place of practice is in Sabah or Sarawak, to the State Attorney General, that any notary public is about to be absent from his place of practice for a period exceeding one month, the Attorney General or 
the State Attorney General, may appoint any person, being a practising advocate, to be a notary public temporarily during the absence of that notary public.

(6) No temporary appointment of a notary public shall have effect for a longer period than twelve months and any such appointment shall lapse on the death or on the return to his place of practice of the notary public on account of whose departure the appointment was made.

(7) Every appointment under subsection (1) or (5) and the lapse of every temporary appointment under subsection (6) shall be published in the Gazette.

\section{Privileges of notaries public}

4. (1) Every notary public shall have and may exercise within his place of practice all the powers and functions which are ordinarily exercised by notaries public in England:

Provided that, except for the purposes of and to the extent necessary to give effect to subsection (2), such powers shall not include power to administer any oath or affirmation in connection with any affidavit or statutory declaration which is executed for the purpose of being used in any court or place within Malaysia, or to take or attest any such affidavit or statutory declaration. (2) Without prejudice to the generality of the powers and functions conferred by subsection (1), a notary public may-- (a) administer any oath or affirmation in connection with any affidavit or statutory declaration which is executed-- (i) for the purpose of confirming or proving the due execution of any document; (ii) by any master or member of the crew of any vessel in respect of any matter concerning that vessel; or (iii) for the purpose of being used in any court or place outside Malaysia, and may take or attest any such affidavit or statutory declaration; and (b) have and exercise such other powers and functions as may be prescribed.

Misconduct of notaries public

5. If it shall appear to the Attorney General or in the case of a temporary appointment in Sabah or Sarawak, to the State Attorney General, that any person being a notary public; (a) has been struck off the roll of advocates or ceased to be licensed as a pleader in the State of Terengganu, as the case may be; or (b) has exercised any of the functions of a notary public outside his place of practice, the Attorney General or the State Attorney General, as the case may be, shall, by order under his hand, revoke the appointment of that person and shall cause the order to be published in the Gazette.

\section{Penalty for exercise of functions of notary public by unauthorized persons}

Any person who exercises, within Malaysia, any of the functions of a notary public otherwise than in accordance with this Act shall be guilty of an offence and shall on conviction before a Sessions Court in Semenanjung Malaysia or the Court of a Magistrate of the First Class in Sabah and Sarawak be liable to fine not exceeding five hundred ringgit.

\section{Rules}

7. (1) The Rules Committee in respect of Peninsular Malaysia and the Chief Judge of the High Court in Sabah and Sarawak after consultation with the State Attorney General concerned in respect of Sabah and Sarawak may make rules-- (a) for the 
guidance and control of persons entitled to exercise the functions of a notary public under this Act; (b) to fix the fees payable to notaries public; (c) to fix the fees payable by any person on appointment as a notary public: Provided that no such rule shall require any fee to be paid in respect of any appointment as a notary public deemed to have been made by virtue of subsection 8(1); and (d) prescribing the powers and functions of notaries public. (2) All rules made under this section shall be published in the Federal Gazette or the Sabah or the Sarawak State Gazette, as the case may be.

8. (1) Any person who immediately before the commencement of this Act was lawfully entitled to practise as a notary public within Peninsular Malaysia or any part thereof (other than a person entitled to practise as a notary public in the State of Johore by virtue of section 4 of the Notaries Public Ordinance 1947 [Ord. 47 of 1947]) shall be deemed to have been appointed a notary public in accordance with this Act to practise as a notary public within Peninsular Malaysia or (if he was entitled to practise only within a part of Peninsular Malaysia) within such part as the case may be. (2) (Omitted), (3) The name of every person who has been deemed to have been appointed a notary public by virtue of subsection (1) shall, within three months of the coming into force of this Act, or such longer period as the Attorney General may in any particular case permit, be published in the Gazette; and such publication shall be conclusive evidence of the right of every such person to practise as a notary public under this section.

9. (1) The Notaries Public Ordinance 1947 is repealed. (2) Notwithstanding the repeal of the said Ordinance any rules made thereunder and in force immediately before the commencement of this Act shall, so far as they are not inconsistent with this Act, be deemed to have been made under this Act, and shall continue in force until revoked or repealed by rules made under this Act, and shall, unless the context otherwise requires, apply and have effect throughout Peninsular Malaysia.

\subsection{Legal Services: Commercial Law}

The corporate and commercial department provides services in all aspects of corporate finance, mergers and acquisitions, corporate restructuring, agency and commercial agreements, competition, business and asset transfers, directors' duties, partnership and private limited company structuring, intellectual property, joint ventures and private equity financing. Advice is also given in relation to contentious and noncontentious employment matters. The team has a strong reputation for a sensible approach to getting the job done ${ }^{11}$.

- Dispute Resolution

Dispute resolution has qualified advocates within the department. The firm adopts a proactive approach to dispute management. The litigation team works closely with a number of national commercial clients and provides specialist advice on commercial disputes, shareholder conflict and indemnity claims, company disputes, partnership and private limited company issues, professional negligence and property litigation. The department also provides advice to insolvency practitioners.

- Conveyancing ${ }^{12}$

\footnotetext{
${ }^{11}$ Boo, Cheng Hau. "Isn't a One-race Civil Service a Form of Apartheid?". The Malaysian Insider. Archived from the original on 21 June 2011.

12 Lau, A., A Moment of Anguish: Singapore in Malaysia and the Politics of Disengagement, Times Academic Press, Singapore, 1998.
} 
There is strength and depth in the commercial and residential property teams across all three of the firm's offices. Commercial work is undertaken for a number of national name clients with property portfolios across the capital city. The work includes property redevelopment, leasing, acquisitions, disposals and compulsory base. Probate, trusts and tax purchase. The department also provides a specialist residential property service. It are also involved in the preparation of Islamic Loan documentation with product such as Bai Bil Taman Ajil and Musharakah Mutanaqisah for with various bank such as Public Islamic Bank Bhd, Hong Leong Islamic Bank, Maybank Islamic Bhd, Bank Islam Bhd and Standard Chartered Islamic Bank Bhd.

- Private Client Services

C.K.Leong \& Nurbaya maintains an enviable and long established private client planning work is dealt with by the regionally recognised italth preservation team, and specialist advice and planning is given for corporate and private property investment clients. Family law is a recognised area of regional expertise and encompasses complex financial affairs ${ }^{13}$, arrangements

- Intellectual Property and Information Technology:

- Trade and Service Marks, Patents, Designs and Copyrights, Licensing and Franchising;

- Corporate Administration and Secretarial Services;

- International Business Transactions, Tax Practice and Planning, Securities and Loans;

\subsection{Apostille and Legalisation ${ }^{14}$}

- Apostille

An Apostille is a certificate issued by the Department of Foreign Affairs of some countries verifying the genuineness of the signature and/or seal of a public officer e.g. a Public notary, on a public document and the capacity in which he or she has acted. The Apostille certificate may be stamped on or attached to the public document required to be apostilled. It is obtained by presenting the document at the Department of Foreign Affairs. The Apostille procedure applies in lieu of Legalisation betiten countries that have signed and ratified or acceded to the Hague Convention of 5 October 1961. Other countries in which the Apostille procedure applies may be checked on the Hague Convention itbsite, where a list of countries adhering to the Apostille system abolishing the need for legalisation, and also those countries not Hague Convention Countries Adhering.

- Legalisation

Legalisation is an internationally recognised procedure for certifying the authenticity of official signatures and/or official seal applied to a public document. It operates by means of an unbroken chain of verifying signatures commencing with that of the first signatory to the document and ending with the signature of the diplomatic or consular representative of the state in which the document is to produced and acted upon. The legalisation procedure usually commences with the attestation by a Public notary of the signature of a person to a formal document. After the Public notary

${ }^{13}$ Crounch, H., Government and Society in Malaysia, Allen and Unwin, Australia, 1966, Chapters 1 and 2.

${ }^{14}$ Puthucheary, M., The Politics of Administration: Th e Malaysian Experience, Oxford University Press, Kuala Lumpur, 1978, p. 11. 
subscribed the signatory's name and affixed his or her official seal to the document by way of notarial act, the document shall be sent to the Ministry of Foreign Affairs which in Kuala Lumpur, itbsite at Ministry of Foreign Affairs of Malaysia Wisma Putra, No 1, Jln. Wisma Putra, Precinct 2, 62602 PUTRAJAYA Phone: +603-8000 8000 / Email : itbmaster@kln.gov.myand paying the appropriate consular fee, normally RM 20.00 per document - for the purpose of having the Notary's signature and official seal verified. The document is then produced at the diplomatic or consular representative or embassy in Kuala Lumpur of the foreign country in which it is intended to be used. The document shall be produced for the purpose of having the Ministry of Foreign Affairs signature legalised. When all the foregoing steps have been completed, the document is said to have been legalised. Other countries in which the Apostille procedure applies may be checked on the the Hague Convention itbsite, where a list of countries adhering to the Apostille system abolishing the need for legalisation, and also those countries not Hague Convention Countries Adhering ${ }^{15}$.

\subsection{Notaries By The Numbers}

Notaries are appointed to act in a specific territory only, either a state or one of the federal territories. Here is the breakdown of where notaries practice in Malaysia:

- Kuala Lumpur: 133

- Selangor: 40

- Penang: 36

- Johor: 26

- Sarawak: 22

- Sabah: 13

- Perak: 12

- Negeri Sembilan: 6

- Melaka: 6

- Kedah: 5

- Pahang: 4

- Labuan: 3

- Putrajaya: 2

- Kelantan: 2

- Terengganu: 1

- Perlis: 0

The figures are taken from the Attorney General's Chambers' itbsite and the total is 311.

Since notaries are appointed from practising lawyers, the number of notaries in a state or FT will tend to reflect the number of lawyers practising there. The size of each state Bar is in turn influenced by the level of local legal and economic activity.

It is therefore no surprise the largest number of notaries, some $43 \%$, are found in Kuala Lumpur. I do feel a little sorry for anyone in Perlis who needs the services of a notary. I suppose it is a short hop over to Kedah, where they have all of five to choose from.

In 2013, there itre 15,331 advocates \& solicitors in Peninsula Malaysia. Only practitioners with more than 15 years' experience are eligible for appointment. I estimate there are about 6,000 who have reached this milestone in their professional

${ }^{15}$ Dreseen, H., A short history of the Malay College, MCKK Golden Jubilee Brochure 1905-1955, cited in Puthucherary, 1978, p.10. 
lives. The 276 notaries in Peninsula Malaysia therefore constitute about $4.6 \%$ of all eligible lawyers in this part of the country.

Are there too few or too many notaries? Certainly it is easier to find a lawyer than to find a notary. Hoitver, I think the numbers regulate themselves. All 6,000 senior lawyers could have applied for appointment but they did not, I suspect, because apart from a lack of interest in this field of law, there is little financial incentive to do so. Notarial fees are prescribed by law, and they have not increased in decades. So lawyers who do take up notarial work are that odd species who either feel the fees justify the effort or, as a fellow notary told me, because they feel it is a form of public service. For myself, both these factors play a role but I also find it quite interesting to meet a wide spectrum of people. It certainly breaks up the monotony of my usual office work.

\section{Closing}

- If the people should require Public notary services for any of the matters listed below the Public notary Act 1959;

- The corporate and commercial department provides services in all aspects of corporate finance, mergers and acquisitions, corporate restructuring, agency and commercial agreements, competition, business and asset transfers, directors' duties, partnership and private limited company structuring, intellectual property, joint ventures and private equity financing.

- the Public notary subscribed the signatory's name and affixed his or her official seal to the document by way of notarial act, the document shall be sent to the Ministry of Foreign Affairs which in Kuala Lumpur, itbsite at Ministry of Foreign Affairs of Malaysia Wisma Putra, No 1, Jln. Wisma Putra, Precinct 2, 62602 PUTRAJAYA Phone: +603-8000 8000 / Email: itbmaster@kln.gov.myand paying the appropriate consular fee, normally RM 20.00 per document - for the purpose of having the Notary's signature and official seal verified.

\section{Bibliography}

\section{Book:}

[1] Boo, Cheng Hau. "Isn't a One-race Civil Service a Form of Apartheid?". The Malaysian Insider. Archived from the original on 21 June 2011.

[2] Chooi, Clara. "Putrajaya Reports Increase in Non-Bumiputeras in Civil Service". The Malaysian Insider.

[3] Chooi, Clara. "Putrajaya Reports Increase in Non-Bumiputeras in Civil Service". The Malaysian Insider.

[4] Crounch, H., Government and Society in Malaysia, Allen and Unwin, Australia, 1966, Chapters 1 and 2.

[5] Dreseen, H., A short history of the Malay College, MCKK Golden Jubilee Brochure 1905-1955, cited in Puthucherary, 1978.

[6] Hai, Jeong Chun; Nawi, Nor Fadzlina (2007). Principles of public administration: an introduction. Shah Alam, Selangor: Karisma Publications.

[7] Lau, A., A Moment of Anguish: Singapore in Malaysia and the Politics of Disengagement, Times Academic Press, Singapore, 1998.

[8] Puthucheary, M., The Politics of Administration: Th e Malaysian Experience, Oxford University Press, Kuala Lumpur, 1978. 


\section{Legislation:}

[1] Act 115

[2] Notaries Public Act 1959

[3] Act 14/1960 Notaries Public (Amendment) 30-05-1960 Act 1960

[4] Act 7/1961 Notaries Public (Amendment) 01-06-1961 Act 1961

[5] L.N. 98/1965 Modification of Laws (Notaries 18-03-1965 Public) (Extension and Modification) Order 1965

[6] Act 160 Malaysian Currency (Ringgit) 29-08-1975

[7] Act 1975

[8] P.U. (A) 357/1980 Subordinate Courts Act 01-06-1981 (Extension) Order 1980

[9] Act A501 Notaries Public (Amendment) 01-08-1991

[10]Act 1980

[11]Act A885 Constitution (Amendment) 24-06-1994

[12]Act 1994

[13]Act A992 Notaries Public (Amendment) 27-06-1997

[14]Act 1997

\section{Internet:}

[1] http://exfacie.com/?q=notaries halsburys laws of england 1st edition, Accessed on $15^{\text {th }}$ February 2019

[2] http://www.agc.gov.my/Akta/Vol.\%209/Act\%20424.pdf, Accessed on 15 February 2019

[3] www.agc.gov.my/Akta/Vol.\%201/Act\%2013.pdf, Accessed on 15 $15^{\text {th }}$ February 2019

[4] https://evisaforms.state.gov/acs/default.asp?postcode=KLL\&appcode=1, Accessed on $15^{\text {th }}$ February 2019 